\title{
The Readily Releasable Pool of Vesicles in Chromaffin Cells Is Replenished in a Temperature-Dependent Manner and Transiently Overfills at $37^{\circ} \mathrm{C}$
}

\author{
Vera Dinkelacker, Thomas Voets, Erwin Neher, and Tobias Moser \\ Department of Membrane Biophysics, Max-Planck-Institute for Biophysical Chemistry, D-37077 Göttingen, Germany
}

\begin{abstract}
Maturation of exocytic vesicles to the release-ready state is regulated by several factors, including intracellular calcium concentration $\left(\left[\mathrm{Ca}^{2+}\right]_{\text {int }}\right)$ and the state of protein phosphorylation. Here we investigated the effects of temperature on the recovery from depletion of the readily releasable pool (RRP) of vesicles in adrenal chromaffin cells. Exocytosis and $\left[\mathrm{Ca}^{2+}\right]_{\text {int }}$ were monitored by combined membrane capacitance and fura-2 measurements. At higher temperatures, a faster pool refilling and a larger RRP size were observed. The time constants of the recovery from depletion ranged from 3.6 to $1.1 \mathrm{sec}\left(22\right.$ and $37^{\circ} \mathrm{C}$, respectively) yielding a $Q_{10}$ of 2.3 . The changes of the $\mathrm{Ca}^{2+}$ signal between the different temperatures could not account for the differences in recovery kinetics. At 32 and $37^{\circ} \mathrm{C}$, we observed a
\end{abstract}

transient overfilling of the RRP after pool depletion, which stands in clear contrast to the sustained secretory depression seen at lower temperatures. The overshoot in RRP size was very prominent in cells with lower basal $\left[\mathrm{Ca}^{2+}\right]_{\text {int }}$, hence with a large difference between prestimulus and poststimulus $\left[\mathrm{Ca}^{2+}\right]_{\text {int. }}$. In cells with higher basal $\left[\mathrm{Ca}^{2+}\right]_{\text {int }}$, the pool was larger under steady-state conditions but showed less overfilling on stimulation. We conclude that vesicle maturation is markedly accelerated at physiological temperature, thus allowing for a rapid adaptation of the pool size to the relatively short-lived $\mathrm{Ca}^{2+}$ transient.

Key words: exocytosis; chromaffin cells; capacitance; vesicle pools; refilling; temperature; calcium
The regulation of a readily releasable pool (RRP) of vesicles has for a long time been discussed as a major mechanism of exocytic plasticity in both neuroendocrine cells and presynaptic terminals (for review, see Zucker, 1999). In this context, the depression of the secretory response and ensuing recovery is interpreted as refilling of a depleted RRP. Previous studies of this recovery process were performed in various preparations (Stevens and Tsujimoto, 1995; Moser and Neher, 1997b; von Gersdorff and Matthews, 1997; Wang and Kaczmarek, 1998; Moser and Beutner, 2000) and revealed regulation by $\mathrm{Ca}^{2+}$ and protein kinases (Smith et al., 1998; Stevens and Sullivan, 1998; Gomis et al., 1999). Adrenal chromaffin cells are embryonically derived from precursors of sympathetic neurons and release catecholamines into the bloodstream using the same conserved fusion machinery that is found in the CNS (Morgan and Burgoyne, 1997). These cells offer the advantage of allowing simultaneous monitoring of cytosolic $\mathrm{Ca}^{2+}$ and high time resolution measurements of secretion. For these reasons, they have been extensively studied as a model system for neurosecretion.

Several studies indicated that temperature has substantial influence on exocytosis. Chromaffin cells under continuous stimulation displayed increased initial amounts and rates of secretion at $37^{\circ} \mathrm{C}$ compared with room temperature (Kao and Westhead, 1984; Park et al., 1999). Thomas et al. (1993b) investigated the influence of temperature on secretion evoked by flash photolysis of $\mathrm{Ca}^{2+}$ using high resolution membrane capacitance measurements in pituitary melanotrophs. They reported a strong enhancement of a slow secretory component most likely reflecting increased supply of release-ready vesicles. This conclusion was also drawn from a study of temperature effects on insulin release from pancreatic B-cells induced by trains of depolarizations (Renstrom et al., 1996).

Received May 22, 2000; revised Aug. 21, 2000; accepted Aug. 24, 2000.

This work was supported by grants of the Deutsche Forschungsgemeinschaft (SFB 523). We thank Dr. Corey Smith for providing analysis routines and for helpful discussions. We thank Drs. Kevin Gillis, Christophe Pouzat, and Ralf Schneggenburger for critical comments on former versions of this manuscript, and we thank F. Friedlein and M. Pilot for expert technical assistance.

Correspondence should be addressed to Vera Dinkelacker, Department of Membrane Biophysics, Max-Planck-Institute for Biophysical Chemistry, Am Fassberg, D-37077 Göttingen, Germany. E-mail: vdinkel@gwdg.de.

Copyright (C) 2000 Society for Neuroscience $0270-6474 / 00 / 208377-07 \$ 15.00 / 0$
The objective of the present study was to monitor the replenishment of release-ready vesicles in a more direct and highly timeresolved manner, considering both the temperature and the $\mathrm{Ca}^{2+}$ dependence of the process. To mimic in vivo conditions, membrane capacitance measurements $\left(C_{\mathrm{m}}\right)$ were performed in the perforatedpatch configuration, which preserves mobile cytosolic components. $\left[\mathrm{Ca}^{2+}\right]$ was recorded simultaneously using fura-2 AM. We examined the recovery time course of the RRP from depolarizationinduced depletion in isolated bovine adrenal chromaffin cells at 22, 27 , and $32^{\circ} \mathrm{C}$ and at physiological temperature $\left(37^{\circ} \mathrm{C}\right)$. Our intention was to distinguish the genuine temperature effects on vesicle dynamics from the indirect effects mediated by changes in $\mathrm{Ca}^{2+}$ signaling. Previous work has shown that the RRP refilling is enhanced at increased intracellular $\left[\mathrm{Ca}^{2+}\right]$. Here we show that the process is highly temperature dependent, such that above $32^{\circ} \mathrm{C}$, the pool size rapidly adapts to the short-lived rise in $\left[\mathrm{Ca}^{2+}\right]_{\text {int }}$.

\section{MATERIALS AND METHODS}

Chromaffin cell culture. Chromaffin cells were prepared by digestion of adult bovine adrenal medulla in collagenase type I $(0.5 \mathrm{mg} / \mathrm{ml}$; Worthington Enzymes, Freehold, NJ) and cultured for 1-4 d. Additional details are described in Smith (1999). After enrichment on a Percoll gradient, cells were plated in DMEM, $1 \times$ GMS-X (a defined serum substitute; Life Technologies, Bethesda, MD), penicillin, and streptomycin at a density of $\sim 4.4 \times 10^{3} / \mathrm{mm}^{2}$. Cultures were maintained at $37^{\circ} \mathrm{C}$ and $10 \% \mathrm{CO}_{2}$.

Solutions. During recordings, cells were constantly superperfused at a rate of $\sim 1 \mathrm{ml} / \mathrm{min}$ with a Ringer's solution of the following composition (in $\mathrm{mm}): 150 \mathrm{NaCl}, 10 \mathrm{HEPES}, 10$ glucose, $2.8 \mathrm{KCl}, 2 \mathrm{MgCl}_{2}, 2 \mathrm{CaCl}_{2}$ (recovery at 32 and $37^{\circ} \mathrm{C}$ ), or $10 \mathrm{CaCl}_{2}$ (all other conditions). The osmolarity was adjusted to $310 \mathrm{mOsm}$ with mannitol, and $\mathrm{pH}$ was adjusted to 7.2 with $\mathrm{NaOH}$. The standard perforated patch solution contained (in $\mathrm{mm}$ ): $145 \mathrm{Cs}$-glutamate, $10 \mathrm{HEPES}, 8 \mathrm{NaCl}, 1 \mathrm{MgCl}_{2}, 0.53$ amphotericin $\mathrm{B} ; \mathrm{pH}$ was adjusted to 7.2 with $\mathrm{CsOH}$, and osmolarity was $300 \mathrm{mOsm}$. Amphotericin B was prepared as described by Smith and Neher (1997). Pipettes were tip-dipped in amphotericin-free solution for 2-10 sec and back-filled with freshly mixed amphotericin-containing solution. The liquid junction potential between the extracellular Ringer's and the pipette filling solution was measured to be $\sim 13 \mathrm{mV}$, and all potentials were adjusted accordingly. All chemicals were obtained from Sigma (St. Louis, MO), with the exception of $\mathrm{CsOH}$ (Aldrich, Milwaukee, WI) and amphotericin B (Calbiochem, La Jolla, CA), or as noted otherwise.

Electrophysiological measurements. Pipettes of $\sim 2-3 \mathrm{M} \Omega$ resistance were pulled from borosilicate glass, partially coated with a silicone compound (G. E. Silicones, Bergen Op Zoom, The Netherlands), and lightly fire- 
polished. For acquisition we used an EPC-9 amplifier and "PULSE" software running on an Apple Macintosh. $C_{\mathrm{m}}$ was estimated by the Lindau-Neher technique (for review, see Gillis, 1995) implemented as the "Sine + D.C." feature of the Pulse lock-in module. An $800 \mathrm{~Hz}, 35 \mathrm{mV}$ peak amplitude sinewave was applied to a holding potential of $-83 \mathrm{mV}$, and the reversal potential of the lock-in module was set to $0 \mathrm{mV}$. Data were acquired through a combination of the high time resolution PULSE software and the lower time resolution X-Chart plug-in module to the PULSE software. Briefly, membrane current was sampled at $10 \mathrm{kHz}$ shortly (100 msec) before, during, and after the depolarizations, and $C_{\mathrm{m}}$ was calculated with a resolution of $800 \mathrm{~Hz}$. Data acquired between high time resolution PULSE protocols were typically sampled at $12 \mathrm{~Hz}$ with the lower time resolution X-Chart plug-in.

Capacitance increases caused by depolarizations were determined from the high time resolution $C_{\mathrm{m}}$ traces as the difference between mean $C_{\mathrm{m}}$ measured in a $13 \mathrm{msec}$ window starting $38 \mathrm{msec}$ after the depolarization minus the mean prestimulus $C_{\mathrm{m}}$, also measured over a $13 \mathrm{msec}$ window. The first $38 \mathrm{msec}$ of the post-depolarization capacitance was neglected to avoid influences of nonsecretory capacitance transients (Horrigan and Bookman, 1994).

Temperature control. Temperatures were adjusted by flow-heating and heating of the objective lens (TC-344B, Warner, Hamden, CT) as well as heating the microscope stage (Luigs and Neumann, Ratingen, Germany). Without heating the objective lens, a pronounced temperature difference of up to $3^{\circ} \mathrm{C}$ was observed between the edge and the center of the coverslip. Temperature was measured close to the recorded cell. Experiments were performed at either $22,27,32$, or $37^{\circ} \mathrm{C}$.

Cytosolic $\mathrm{Ca}^{2+}$ measurements. After the cells were preincubated in growth medium containing $1 \mu \mathrm{M}$ fura-2 AM (Molecular Probes, Eugene, OR) for $20 \mathrm{~min}$ at $37^{\circ} \mathrm{C}$, cellular $\mathrm{Ca}^{2+}$ concentrations were measured in the perforated-patch configuration by excitation of the dye with light alternated between 360 and $390 \mathrm{~nm}$ using a monochromator-based system (TILL Photonics, Planegg, Germany). Once the experimental protocol was finished, the perforated patch was ruptured, causing the intracellular fura-2 to dialyze out of the cell, allowing for the measurement of the autofluorescence of the cell. The autofluorescence values at 360 and 390 $\mathrm{nm}$ wavelength excitation were subtracted from values measured during the experiment, and the $\left[\mathrm{Ca}^{2+}\right]_{\text {int }}$ was estimated according to Grynkiewicz and colleagues (1985).

\section{RESULTS}

\section{The secretory response to dual-pulses at different temperatures}

Chromaffin cells were stimulated by pairs of depolarizations (Fig. 1). This stimulus, termed a dual-pulse (Gillis et al., 1996), is designed to elicit secretory depression by means of two identical $\mathrm{Ca}^{2+}$ current injections given in rapid succession. A value $<1$ for the ratio $(R)$ of the two capacitance responses $\left(R=C_{\mathrm{m} 2} / C_{\mathrm{m} 1}\right)$ represents secretory depression, presumably because of the depletion of the RRP. The sum $\left(S=C_{\mathrm{m} 1}+C_{\mathrm{m} 2}\right)$ is a suitable estimate of the size of the RRP of vesicles (Fig. $1 A$ ) if depletion is observed. In the temperature range investigated, substantial pool depletion occurred as shown in Figure $1, A$ and $B$, as well as Table 1. Nevertheless, $\mathrm{Ca}^{2+}$ currents were not always large enough to elicit sufficient depression. Therefore, we limited the analysis to the pairs of dual-pulses with $R<0.7$ for the first depleting dual-pulse. This excluded $\sim 40 \%$ of the dual-pulses from the data set acquired at $22^{\circ} \mathrm{C}$ and a comparable percentage at higher temperatures (Table 1).

In Figure $1 A$, a typical response of a cell at room temperature $\left(22^{\circ} \mathrm{C}\right)$ is shown. Experimental parameters were chosen to maximize the stimulus-induced depression; e.g., we used $10 \mathrm{~mm}$ $\left[\mathrm{Ca}^{2+}\right]_{\text {ext }}$ to provide for large $\mathrm{Ca}^{2+}$ current amplitudes and used long durations of depolarizations $(100 \mathrm{msec})$. At 32 and $37^{\circ} \mathrm{C}$, a high percentage of dual-pulses evoked rapid endocytosis (data not shown). In these cases, the $C_{\mathrm{m}}$ measurements, which track net changes in cell surface, do not allow for determination of the exact amount of exocytosis. By lowering $\left[\mathrm{Ca}^{2+}\right]_{\text {ext }}$ from 10 to $2 \mathrm{~mm}$, we were able to drastically reduce the incidence of rapid endocytosis (Fig. $1 B, 37^{\circ} \mathrm{C}, 2 \mathrm{~mm}\left[\mathrm{Ca}^{2+}\right]_{\text {ext }}$ ). This is in line with the previously observed $\left[\mathrm{Ca}^{2+}\right]$ dependence of rapid endocytosis (Artalejo et al., 1995; Smith and Neher, 1997; Engisch and Nowycky, 1998; Mansvelder and Kits, 1998). The use of $10 \mathrm{~mm}\left[\mathrm{Ca}^{2+}\right]_{\text {ext }}$ at 22 and $27^{\circ} \mathrm{C}$ and $2 \mathrm{~mm}$ at 32 and $37^{\circ} \mathrm{C}$ allowed for reliable measurements of the exocytic response. These conditions were used for all of the data presented below.

At $37^{\circ} \mathrm{C}$, the secretory response was markedly enhanced as compared with room temperature, despite apparently smaller
$\mathrm{Ca}^{2+}$ currents (Fig. $1 B$ ). The $\mathrm{Ca}^{2+}$-exocytosis relationship at the different temperatures was further investigated as shown in Figure $1 C$. The large range of the $\mathrm{Ca}^{2+}$ currents in this analysis most likely originates from rundown during an experiment, possibly also from differences in the size of the chromaffin cells and the set of $\mathrm{Ca}^{2+}$ channels. Despite considerable scatter, there is a discernible trend of higher secretion amplitudes for a given $\mathrm{Ca}^{2+}$-current magnitude with the rise in temperature. Between 45 and $50 \mathrm{pC}$, a range that approximates the overall average $\mathrm{Ca}^{2+}$ current integral to a $100 \mathrm{msec}$ depolarization, the mean capacitance responses were $36 \pm 4 \mathrm{fF}$ at $22^{\circ} \mathrm{C}, 60 \pm 2 \mathrm{fF}$ at $27^{\circ} \mathrm{C}, 132 \pm 10 \mathrm{fF}$ at $32^{\circ} \mathrm{C}$, and $162 \pm$ $15 \mathrm{fF}$ at $37^{\circ} \mathrm{C}$.

\section{Recovery from pool depletion at room temperature}

To monitor the recovery of the RRP from depletion, we estimated the size of the RRP at resting conditions with an initial dual-pulse. This stimulus had to be strong enough to deplete the pool of release-ready vesicles. A second dual-pulse was applied at varying time intervals to probe the recovery from depletion.

Figure $2 A$ displays the recovery time course, i.e., the RRP size estimates $(S)$ of a representative cell at $22^{\circ} \mathrm{C}$ as a function of the interpulse interval. The pooled data of the nine cells measured at room temperature and their average changes in cytosolic $\left[\mathrm{Ca}^{2+}\right]_{\text {int }}$ are shown in Figure $2 B$. Note also the basal $\mathrm{Ca}^{2+}$ concentration at $22^{\circ} \mathrm{C}$ and elevated temperatures as given in Figure $3 E$.

The recovery of pool size shows a rapid onset while the decaying $\left[\mathrm{Ca}^{2+}\right]_{\text {int }}$ is still high, because of a strong $\mathrm{Ca}^{2+}$ enhancement of the vesicle supply [Smith et al. (1998); data acquired at room temperature], whereas steady-state values are slowly approached after $\left[\mathrm{Ca}^{2+}\right]_{\text {int }}$ has decayed to basal values. The steady-state pool size as determined between 30 and $65 \mathrm{sec}$ after the depleting stimulus was $62 \pm 2 \mathrm{fF}$ (also see Table 1). Assuming a mean capacitance of $\sim 2$ $\mathrm{fF}$ per dense-core vesicle in adrenal chromaffin cells (estimates range from 1.3 to $2.7 \mathrm{fF}$ ) (Neher and Marty, 1982; Chow et al., 1996; Albillos et al., 1997; Moser and Neher, 1997a), this pool size corresponds to $\sim 30$ vesicles.

\section{$\mathrm{Ca}^{2+}$ kinetics at different temperatures}

To compare the kinetics of the vesicle supply at different temperatures, we had to address the following issue. Pool-depleting depolarizations lead to a rise in $\left[\mathrm{Ca}^{2+}\right]_{\text {int }}$ within the time window of vesicle replenishment. Accordingly, the genuine temperature dependence of the recovery process can only be approximated if the properties of the $\mathrm{Ca}^{2+}$ signal remain similar throughout the temperature range investigated. We therefore analyzed the $\mathrm{Ca}^{2+}$ currents as well as the resulting changes of cytosolic $\left[\mathrm{Ca}^{2+}\right]$ monitored by fura- 2 measurements (Fig. $3 A-E$ ).

The summed $\mathrm{Ca}^{2+}$ current integral of the paired $\mathrm{Ca}^{2+}$ current injections, a measure of the stimulus strength, is shown in Figure $3 \mathrm{~A}$. The current integrals were comparable for 22 and $37^{\circ} \mathrm{C}$ at 10 $\mathrm{mM}\left[\mathrm{Ca}^{2+}\right]_{\text {ext }}$, whereas they were smaller at $37^{\circ} \mathrm{C}$ and $2 \mathrm{~mm}$ $\left[\mathrm{Ca}^{2+}\right]_{\text {ext }}$ (Fig. $3 A$ ). Note that we used $10 \mathrm{~mm}\left[\mathrm{Ca}^{2+}\right]_{\text {ext }}$ at 22 and $27^{\circ} \mathrm{C}$ and $2 \mathrm{~mm}\left[\mathrm{Ca}^{2+}\right]_{\text {ext }}$ at 32 and $37^{\circ} \mathrm{C}$ in all of the experiments presented above and for the following set of analysis.

The origins of the smaller $\mathrm{Ca}^{2+}$ current integrals at higher temperatures, most obvious at $37^{\circ} \mathrm{C}$, are twofold. On one hand, the reduction in external $\left[\mathrm{Ca}^{2+}\right]$ leads to slightly smaller peak $\mathrm{Ca}^{2+}$ currents (Fig. $3 B$ ). On the other, the $\mathrm{Ca}^{2+}$ currents inactivate much faster at $37^{\circ} \mathrm{C}$ as compared with room temperature (Fig. $3 B$; see also Fig. $1 A, B)$. Such speeding of the inactivation of $\mathrm{Ca}^{2+}$ currents at higher temperatures has also been reported for melanotropic cells (Mansvelder and Kits, 1998). Given the equivalent or smaller $\mathrm{Ca}^{2+}$ current integrals as compared with $22^{\circ} \mathrm{C}$, the increased amount of secretion at higher temperatures is not the result of a stronger stimulus. Rather, an enhanced effectiveness of $\mathrm{Ca}^{2+}$ eliciting exocytosis must be postulated.

Decreased peak values for $\left[\mathrm{Ca}^{2+}\right]_{\text {int }}$ were found at higher temperatures (Fig. $3 C$ ), mostly because of the lower $\left[\mathrm{Ca}^{2+}\right]_{\text {ext }}$ at 32 and $37^{\circ} \mathrm{C}$. Although faster than at $22^{\circ} \mathrm{C}$, the decay time constants did not differ significantly between 27,32 , and $37^{\circ} \mathrm{C}$ (Fig. $3 D$ ). Thus, the 

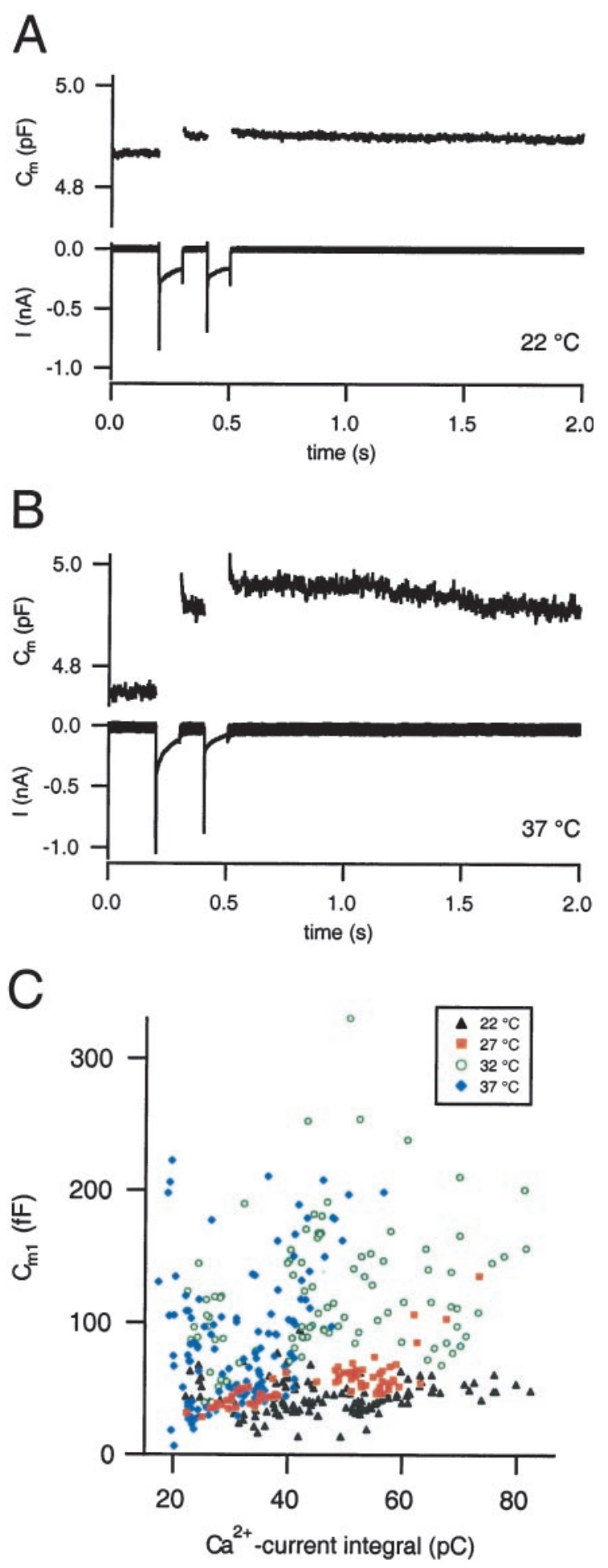

Figure 1. The secretory response at different temperatures. $A$, Example of the $\mathrm{Ca}^{2+}$ currents (bottom trace) and capacitance responses $\left(C_{\mathrm{m}}\right.$, top trace) to a dual-pulse of a cell held in the perforated patch mode at room temperature $\left(22^{\circ} \mathrm{C}\right)$. Two step depolarizations of $100 \mathrm{msec}$ with a $100 \mathrm{msec}$ interval were applied. The depolarization potentials were adjusted such that the two $\mathrm{Ca}^{2+}$ current injections matched closely. Summed response $S=40 \mathrm{fF}$; ratio $R=$ $0.18 . \mathrm{B}, \mathrm{Ca}^{2+}$ currents and capacitance responses of a cell at $37^{\circ} \mathrm{C} . S=206$ $\mathrm{fF} ; R=0.23$. Note the strong increase in capacitance response compared with $22^{\circ} \mathrm{C}$ and the pronounced $\mathrm{Na}^{+}$current gating artifact (Horrigan and Bookman, 1994). A slightly diminished $\mathrm{Ca}^{2+}$ current amplitude of the second pulse was tolerated because residual $\left[\mathrm{Ca}^{2+}\right]_{\text {int }}$ is expected to enhance the stimulus strength. $C$, Exocytosis- $\mathrm{Ca}^{2+}$ relationship. The first capacitance response of a dual-pulse $\left(C_{\mathrm{m} 1}\right)$ under steady-state conditions was plotted versus the $\mathrm{Ca}^{2+}$ current integral of the corresponding depolarization. Filled black triangles are data at $22^{\circ} \mathrm{C}$, filled red squares at $27^{\circ} \mathrm{C}$, green circles at $32^{\circ} \mathrm{C}$, and filled blue diamonds at $37^{\circ} \mathrm{C}$. Exocytic responses to a given $\mathrm{Ca}^{2+}$ stimulus became larger with the rise in temperature. observed acceleration of the recovery process at higher temperatures relative to $27^{\circ} \mathrm{C}$ (see below) cannot be explained by any concomitant change in the kinetics or amplitudes of poststimulus $\left[\mathrm{Ca}^{2+}\right]$.

\section{RRP recovery at elevated temperatures}

The time courses of the recovery from pool depletion at different temperatures are shown in Figure 4. The absolute values were corrected for rundown during an experiment by normalizing the S-value of a dual-pulse to the one of the preceding depleting dual-pulse. This preceding stimulus had been applied at resting $\left[\mathrm{Ca}^{2+}\right]_{\text {int }}$, with a time interval of $\sim 50 \mathrm{sec}$ to its predecessor.

Assuming that each stimulus releases the same fraction of the pool, the intercept $S_{\text {int }}$ at time 0 is derived according to $S_{\text {int }}=$ $S_{0} \times R^{2}$, with $S_{0}=1$ for the normalized data (Gillis et al., 1996). The average ratios $R$ for the different temperatures are given in Table 1 . $R$ was $0.45 \pm 0.01$ at room temperature, including only those dual-pulses that follow the depletion criteria. This yields $S_{\text {int }}$ $=0.20$ as an estimate of the relative initial pool size immediately after the dual-pulse.

The decay time constants $\left(\tau_{\mathrm{dec}}\right)$ of the cytosolic $\left[\mathrm{Ca}^{2+}\right]$ were shown to be $3-4 \mathrm{sec}$ for the temperatures investigated (Fig. $3 D$ ). A time window of $3 \times \tau_{\mathrm{dec}}(10 \mathrm{sec})$ was chosen for analysis of RRP refilling, in which $\left[\mathrm{Ca}^{2+}\right]$ was assumed to be comparably elevated at the different temperatures. For the normalized recovery data acquired at room temperature, exponential fitting in this time window yielded a time constant of $3.6 \mathrm{sec}$ (Fig. $4 A$ ).

Raising the temperature led to both an increase in the secretory response and an acceleration of the recovery from pool depletion (Fig. $4 A-D$ ). These effects were moderate at $27^{\circ} \mathrm{C}$ (Fig. $4 B$ ) but very pronounced when reaching higher temperatures. The steadystate RRP size at basal $\left[\mathrm{Ca}^{2+}\right]$ as well as the time constants of the RRP recovery at the different temperatures are summarized in Table 1.

At $32^{\circ} \mathrm{C}$, the time constant of recovery was $1.7 \mathrm{sec}$. The steadystate pool size was more than doubled $[151 \pm 10 \mathrm{fF}$ corresponding to 75 vesicles (Table 1)]. From the fit at $37^{\circ} \mathrm{C}$, a time constant of 1.1 $\mathrm{sec}$ is derived. This value has to be taken with some caution because the pool size of the initial depleting stimulus is already restored within $<1 \mathrm{sec}$ (Fig. $4 D$ ). The fast time course indicates that some vesicle recruitment may already have occurred during the stimulation episode $(300 \mathrm{msec})$, thus limiting the accuracy of our stimulation protocol.

The temperature dependence of the rate constants of recovery ( $k$, the reciprocal of the time constant) was reasonably well fitted by the Arrhenius equation (Fig. $4 E$ ):

$$
k(T)=A e^{-\frac{\mathrm{E}_{\mathrm{A}}}{\mathrm{RT}}}
$$

where $E_{\mathrm{A}}$ represents the energy of activation of the process, $R$ represents the molar gas constant, and $A$ represents an empirical factor (Arrhenius, 1901; Atkins, 1986). This type of relationship suggests that the same reaction step remains rate-limiting over the temperature range investigated. From the $E_{\mathrm{A}}$ value of $63 \mathrm{~kJ} / \mathrm{mol}$, the $Q_{10}$ was calculated according to $Q_{10}=k(T+10 \mathrm{~K}) / k(T)$, yielding a value of 2.3 at $22^{\circ} \mathrm{C}$.

The $Q_{10}$ values of chemical reactions generally lie between 2 and 4 , whereas those of physical processes such as diffusion range between 1.1 and 1.4 (Precht et al., 1973). Hence, our findings rather point toward a temperature-sensitive protein reaction than to a mere acceleration of vesicle transport attributable to diffusional processes.

\section{The RRP transiently overfills at 32 and $37^{\circ} \mathbf{C}$}

At elevated temperatures, we observed a marked change in the recovery behavior. At both 32 and $37^{\circ} \mathrm{C}$, the RRP size exceeded the level of the previous pulse for a brief period after stimulation and relaxed toward the lower steady-state pool size within $\sim 20 \mathrm{sec}$ (Fig. $4 C, D)$. This prominent overshoot of the RRP size is likely to be a consequence of the marked acceleration of vesicle recruitment at 
Table 1. Summary of the recovery data (values are given as mean \pm SEM)

\begin{tabular}{|c|c|c|c|c|c|c|}
\hline & RRP size (fF) & $\begin{array}{l}R \text { of analyzed } \\
\text { data }\end{array}$ & $S_{\text {int }}$ & $\begin{array}{l}\text { Recovery time } \\
\text { constant }(\mathrm{sec})\end{array}$ & $\begin{array}{l}R \text { of all data } \\
\text { points }\end{array}$ & $\begin{array}{l}\text { Data points } \\
R>0.7 \text { (percentage) }\end{array}$ \\
\hline $22^{\circ} \mathrm{C}$ & $62 \pm 2$ & $0.45 \pm 0.01$ & 0.20 & 3.6 & $0.74 \pm 0.07$ & $42 \pm 8$ \\
\hline $27^{\circ} \mathrm{C}$ & $73 \pm 2$ & $0.48 \pm 0.01$ & 0.23 & 3.2 & $0.56 \pm 0.04$ & $21 \pm 5$ \\
\hline $32^{\circ} \mathrm{C}$ & $151 \pm 10$ & $0.46 \pm 0.01$ & 0.21 & 1.7 & $0.60 \pm 0.04$ & $35 \pm 8$ \\
\hline $37^{\circ} \mathrm{C}$ & $158 \pm 11$ & $0.43 \pm 0.01$ & 0.18 & 1.1 & $0.86 \pm 0.13$ & $42 \pm 8$ \\
\hline
\end{tabular}

A

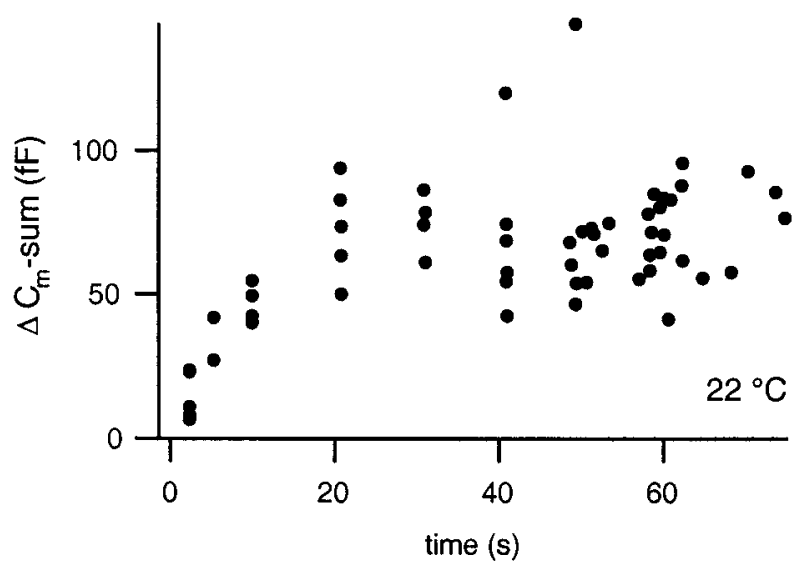

B

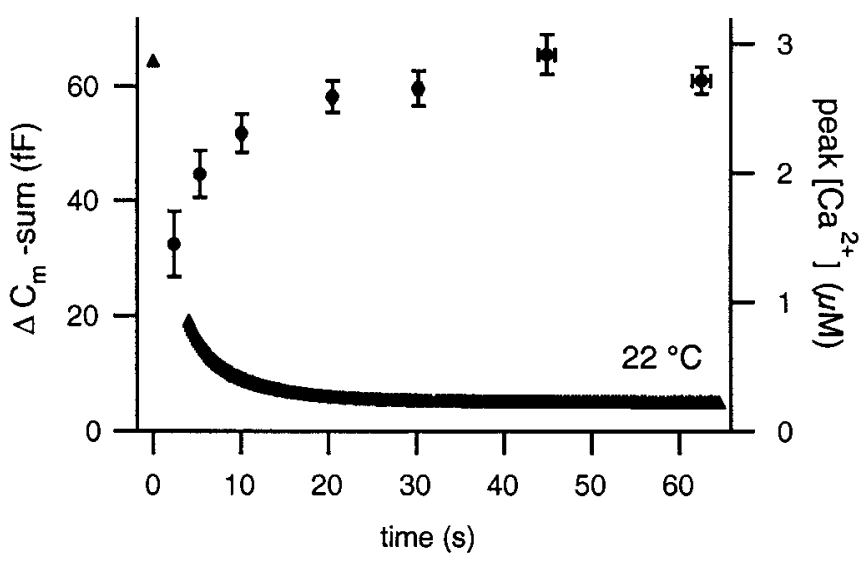

Figure 2. Analysis of capacitance responses to paired depolarizations. $A$, Summed capacitance responses of a representative cell at $22^{\circ} \mathrm{C}$ plotted versus the interpulse interval. The shortest time interval between dualpulses was $2 \mathrm{sec}$ at $22^{\circ} \mathrm{C}$ and $0.5 \mathrm{sec}$ for all other temperatures. $B$, Averaged capacitance responses $(\bullet)$ and fura-2 AM measured $\left[\mathrm{Ca}^{2+}\right]_{\text {int }}(\boldsymbol{\Delta})$ of nine cells. The steady-state pool size is $62 \pm 2 \mathrm{fF}$ as determined by an average of the points at $30 \mathrm{sec}$ and longer time intervals. The peak $\left[\mathrm{Ca}^{2+}\right]_{\text {int }}$ was measured within the first $20 \mathrm{msec}$ after the second depolarization.

elevated $\left[\mathrm{Ca}^{2+}\right]_{\text {int }}$ (Smith et al., 1998). If elevated temperature further increases the recruitment rate, it is possible that the RRP overfills before $\left[\mathrm{Ca}^{2+}\right]_{\text {int }}$ decays back to baseline; then the overshoot should be more prominent, the larger the difference in prestimulus and poststimulus $\left[\mathrm{Ca}^{2+}\right]_{\text {int }}$.

To examine this possibility, we divided the cells at $37^{\circ} \mathrm{C}$ into groups with lower and higher basal $\left[\mathrm{Ca}^{2+}\right]$ (Fig. 5). Four cells with $\left[\mathrm{Ca}^{2+}\right]_{\text {int }}<250 \mathrm{~nm}($ mean $189 \pm 6 \mathrm{nM})$ had an average RRP size of $85 \pm 10 \mathrm{fF}$ (Fig. $5 B$ ). Under the conditions of low basal $\left[\mathrm{Ca}^{2+}\right]_{\text {int }}$, a very pronounced poststimulus augmentation was observed (Fig. $5 A$ ). As soon as $500 \mathrm{msec}$ after the first dual-pulse, the secretory response exceeded the previous response, reaching a maximum of

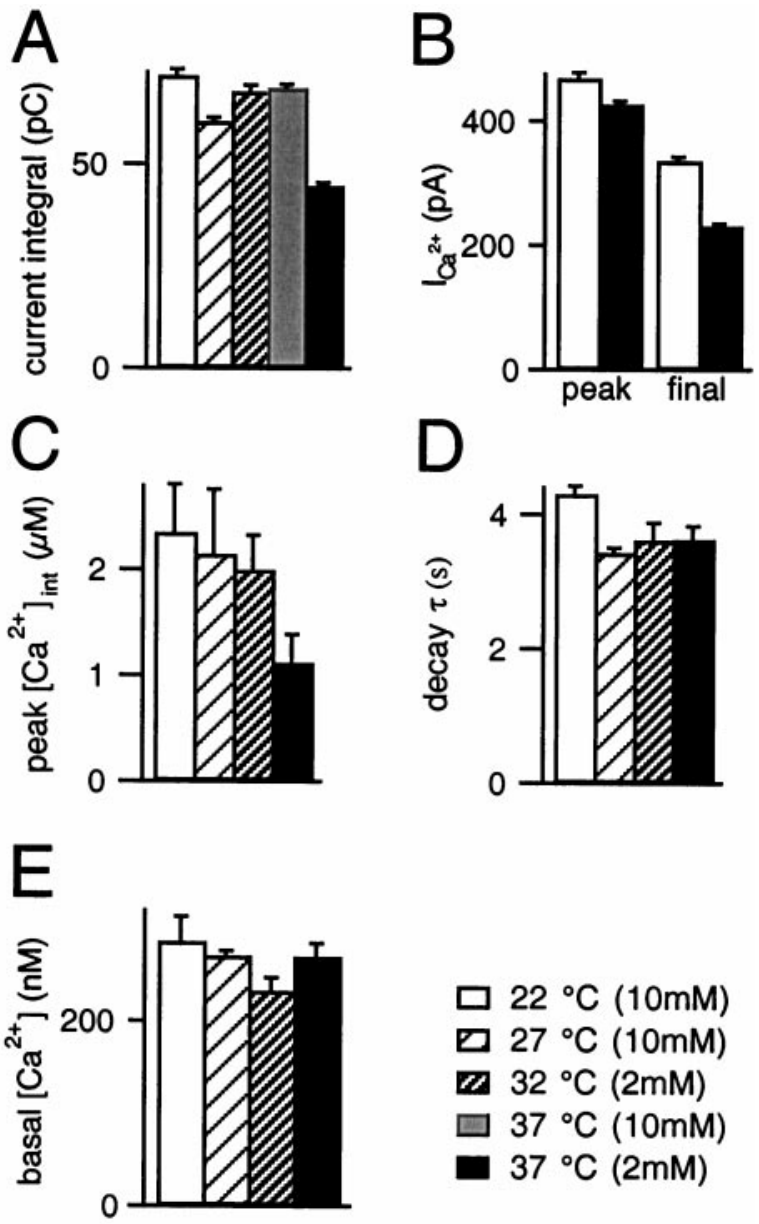

Figure 3. Properties of the $\mathrm{Ca}^{2+}$ signal at different temperatures. $A$, Summed $\mathrm{Ca}^{2+}$ current integrals of dual-pulses at different temperatures, including the value at $37^{\circ} \mathrm{C}$ and $10 \mathrm{mM}\left[\mathrm{Ca}^{2+}\right]_{\mathrm{ext}}(n=7) . B$, Peak $\mathrm{Ca}^{2+}$ currents at 22 and $37^{\circ} \mathrm{C}$ (left ) as determined from the first of the dual-pulses, 5 msec average at $5 \mathrm{msec}$ after the onset of the current, i.e., after $\mathrm{Na}^{+}$ current inactivation. The final $\mathrm{Ca}^{2+}$ currents (right, $5 \mathrm{msec}$ average at $95-100 \mathrm{msec}$ ) attain 70 and $55 \%$ of the peak currents at 22 and $37^{\circ} \mathrm{C}$, respectively. $C$, Peak cytosolic $\left[\mathrm{Ca}^{2+}\right]$ from fura-2 AM measurements (average of the mean of all cells). $D$, Decay time constants of $\left[\mathrm{Ca}^{2+}\right]_{\text {int }}$ derived from exponential fits of the first five dual-pulses of five cells at each temperature (data not shown); the peak $\left[\mathrm{Ca}^{2+}\right]$ and the ensuing $3 \mathrm{sec}$ were not included in the fit. $E$, Basal cytosolic $\left[\mathrm{Ca}^{2+}\right]$ from fura- $2 \mathrm{AM}$ measurements (steady-state values after the first 5 stimulations were averaged over $2 \mathrm{sec})$.

$\sim 1.75$ times the steady-state pool size after 2 sec. Approximately $10 \mathrm{sec}$ after the stimulus, when $\left[\mathrm{Ca}^{2+}\right]$ had returned to basal values (Fig. $5 B$ ), the $C_{\mathrm{m}}$ response started to decay from the overfilled to the steady-state level. This time course is consistent with the postulated $\mathrm{Ca}^{2+}$ enhancement of the vesicle supply.

Four other cells had a basal $\left[\mathrm{Ca}^{2+}\right]$ between 250 and $400 \mathrm{~nm}$ (mean $348 \pm 11 \mathrm{~nm}$ ). Their steady-state RRP size was twice that of the cells at lower basal $\left[\mathrm{Ca}^{2+}\right](170 \pm 23 \mathrm{fF})$ (Fig. $\left.5 B\right)$, which again is in line with the expected $\mathrm{Ca}^{2+}$ effect on the vesicle supply. In this 

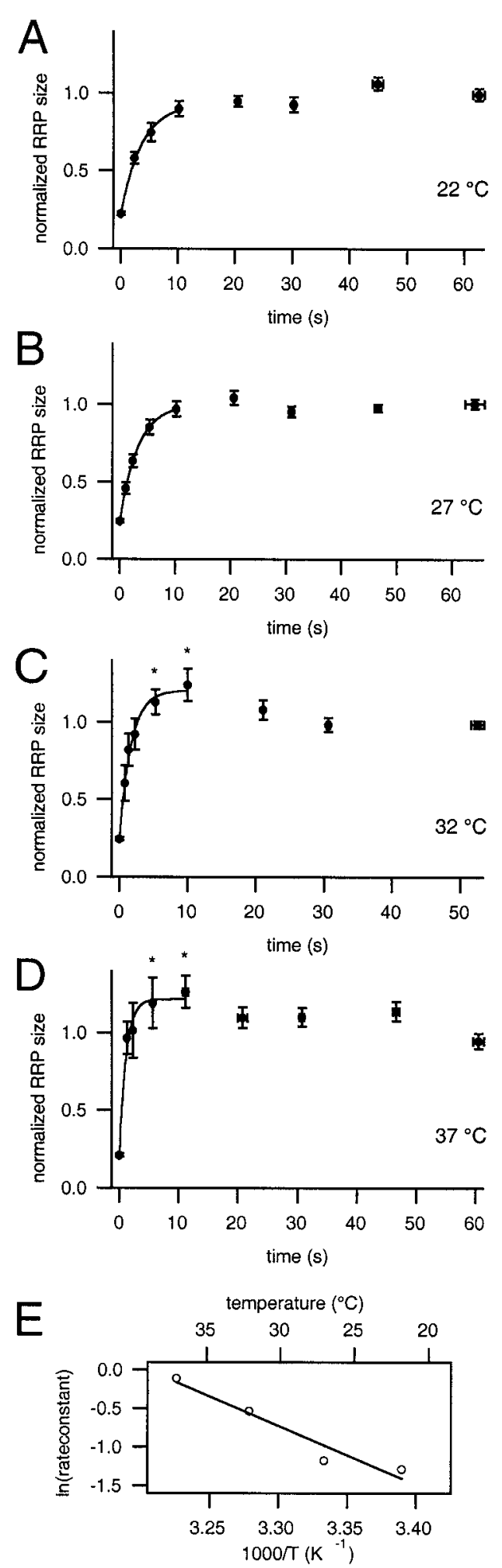

Figure 4. Normalized RRP size at different temperatures. Sum capacitance responses were normalized to the previous dual-pulse, averaged, and plotted versus the interpulse interval. Data points up to $10 \mathrm{sec}$ were fit by a monoexponential. $A, 22^{\circ} \mathrm{C}(9$ cells $), t=3.6 \mathrm{sec} ; B, 27^{\circ} \mathrm{C}(5$ cells $), t=3.2 \mathrm{sec} ; C, 32^{\circ} \mathrm{C}$ (7 cells), $t=1.7 \mathrm{sec}$. Data points marked with an asterisk are significantly different from the steady-state value $(p<0.02) . D, 37^{\circ} \mathrm{C}(8$ cells $), t=1.1 \mathrm{sec}$; data marked by an asterisk are significantly different from steady-state value $(p<0.05) . E$, Arrhenius plot of the rate constants: rate constants were derived from monoexponential fits in $A-D$. Their logarithms were plotted versus 1000/T (absolute temperature); the top axis shows the corresponding temperatures in degrees centigrade. The slope of the line fit yields an energy of activation of $63 \mathrm{~kJ} / \mathrm{mol}$. The $Q_{10}$ as calculated from the Arrhenius equation is 2.3 at $22^{\circ} \mathrm{C}$. data set, the capacitance response attained within the first $2 \mathrm{sec}$ after depletion was comparable with the one in the cells at lower basal $\left[\mathrm{Ca}^{2+}\right]$ (Fig. $5 A$, inset). However, the pool size continued to rise to the much larger steady-state size, showing hardly any overshoot during the recovery from depletion.

These findings suggest that the overfilling of the RRP is reflective of the accelerated vesicle transitions at elevated temperatures, which allow for a dynamic adaptation of the RRP to the short-lived rise in $\left[\mathrm{Ca}^{2+}\right]_{\text {int }}$.

\section{DISCUSSION}

In this study, we have provided evidence that the maturation of vesicles to the release ready state is markedly enhanced at physiological temperature. As a result, restoration of full exocytic competence is faster and secretory efficiency is higher when compared with room temperature, the condition under which secretion experiments are usually performed. The accelerated vesicle replenishment at elevated temperatures did not originate from a stronger stimulus because the $\mathrm{Ca}^{2+}$ signals were comparable to or smaller than those at room temperature.

Our conclusion of a strong temperature dependence of the vesicle supply is in line with the biochemical data of Bittner and Holz (1992), who showed a highly temperature-sensitive step in the secretory process after an ATP-dependent step and preceding the final $\mathrm{Ca}^{2+}$-dependent fusion of vesicles. Previous electrophysiological data also support an enhanced recruitment of vesicles at higher temperatures (Thomas et al., 1993b; Renstrom et al., 1996).

In addition, our study provides a quantitative and highly timeresolved description of the RRP recovery from depletion at different temperatures.

Beyond the anticipated acceleration by temperature, the data reveal a transient overfilling of the RRP at 32 and $37^{\circ} \mathrm{C}$. This overfilling reflects the $\mathrm{Ca}^{2+}$ dependence of the vesicle supply because it is more prominent the larger the difference in prestimulus and poststimulus $\left[\mathrm{Ca}^{2+}\right]_{\text {int }}$. The RRP size exceeds the steadystate value during the short-lasting elevation of $\left[\mathrm{Ca}^{2+}\right]_{\text {int }}$ and relaxes back toward it once $\left[\mathrm{Ca}^{2+}\right]_{\text {int }}$ has declined to baseline. This dynamic adaptation of the secretory response to the rise in $\left[\mathrm{Ca}^{2+}\right]_{\text {int }}$ stands in clear contrast to the pronounced depression at $22^{\circ} \mathrm{C}$, which lasts several seconds. At 32 and $37^{\circ} \mathrm{C}$, the time window of depression is hardly perceived. Rather, the quick onset of augmentation is the most prominent feature. This discrepancy sheds some doubt on the simple extrapolation from data acquired at room temperature to the findings at physiological temperature.

The accelerated vesicle replenishment and ensuing transient overfilling at elevated temperatures are indicative of a faster equilibration between the RRP and proximal vesicle pools. When this overshoot was simulated with the two-step model of secretion control (Heinemann et al., 1993; Smith et al., 1998), the relaxation toward the steady-state pool size at basal $\left[\mathrm{Ca}^{2+}\right]_{\text {int }}$ could only be accounted for if both forward and backward rate of exchange between RRP and reserve pool were increased by temperature.

Recently, a refined model of secretion has been proposed (Voets et al., 1999) that is based on the comparison between the vesicle populations released in response to voltage-dependent $\mathrm{Ca}^{2+}$ influx and flash-photolysis of caged $\mathrm{Ca}^{2+}$. Flash-photolysis elicits a biphasic exocytic burst. In the model, the RRP recruited by depolarizations corresponds to the vesicle population released during the fast component of the burst. The slow component, termed the slowly releasable pool (SRP), remains after RRP depletion. It constitutes an intermediate to the formerly described reserve pool of vesicles. The SRP can only be directly fused during prolonged episodes of high $\left[\mathrm{Ca}^{2+}\right]_{\text {int }}$ and may be involved in the rapid resupply of vesicles to the RRP.

Because our study was focused on depolarization-induced secretion, the observed temperature effects reflect changes of the RRP rather than of the SRP. In a flash photolysis study on melanotrophs, Thomas et al. (1993a,b) did not observe a significant increase of the exocytic burst amplitude when increasing the temperature from 24 to $34^{\circ} \mathrm{C}$. Our study, however, reveals an increase of pool size by a 
Figure 5. Refill kinetics at low and high basal $\left[\mathrm{Ca}^{2+}\right] . A$, Cells with low basal $\left[\mathrm{Ca}^{2+}\right]$ (mean $189 \pm 14 \mathrm{nM}, \mathbf{O}$ ) display a very prominent overshoot of the pool size shortly after the stimulus. The values marked with asterisks (at 1,2 , and $5 \mathrm{sec}$ ) are significantly different $(p<0.05)$ from both the steady-state values and the respective values at higher basal $\left[\mathrm{Ca}^{2+}\right]$ (mean $348 \pm 25 \mathrm{~nm}, n=4, \bigcirc$ ). Both populations displayed similar depletion levels as indicated by $S_{\text {int. }}$. The inset shows the rundown-corrected capacitance responses in absolute values. Note that the responses attained within the first $2 \mathrm{sec}$ after depletion were comparable in both data sets. At high basal $\left[\mathrm{Ca}^{2+}\right]$, however, the pool size continued to rise to the much larger steady-state size. $B$, RRP size and properties of the $\mathrm{Ca}^{2+}$ signal for cells with low and high basal $\left[\mathrm{Ca}^{2+}\right](189 \mathrm{nM}$, black bars; $348 \mathrm{nM}$, white bars).
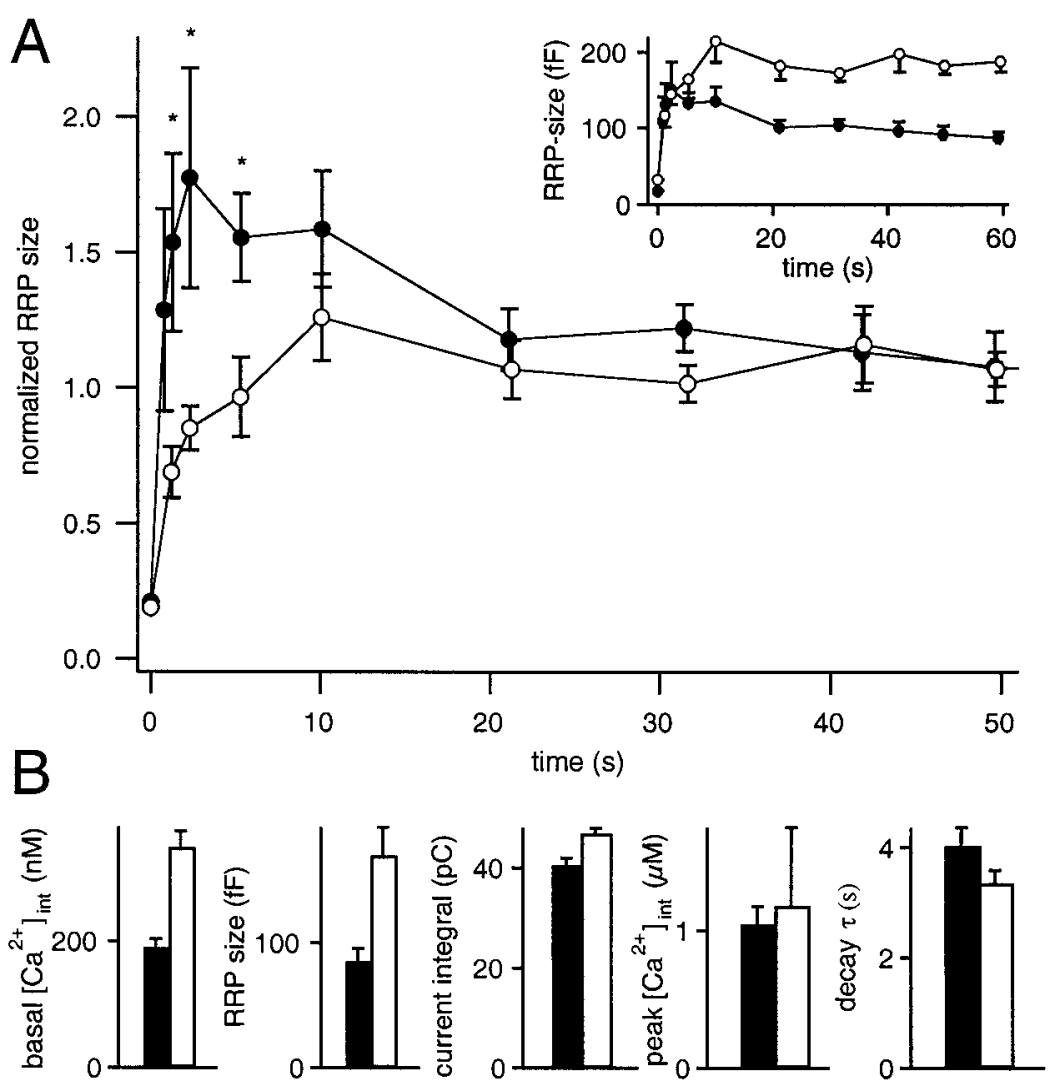

factor of 2 when the temperature is raised by $10^{\circ} \mathrm{C}$. These findings could be reconciled if the vesicle transitions that we observed originated from a shift between the SRP and the RRP and the flash experiments of Thomas and colleagues $(1993 \mathrm{a}, \mathrm{b})$ determined the sum of the SRP and the RRP.

How do the data obtained in neuroendocrine cells relate to neurons? The results of Hardingham and Larkman (1998), who found that synaptic connections became successively more reliable with the elevation of temperature, can well be explained with an increased number of readily releasable vesicles at higher temperatures, as described here for neuroendocrine cells. As to the refilling of the RRP, the time constants reported in neuronal preparations range from 3 to $10 \mathrm{sec}$ at room temperature (von Gersdorff and Matthews, 1997; Stevens and Sullivan, 1998; Stevens and Wesseling, 1998; Weis et al., 1999) and at $36^{\circ} \mathrm{C}$ (Stevens and Tsujimoto, 1995). Interestingly, a recent direct comparison of the recovery process at 25 and $35^{\circ} \mathrm{C}$ in hippocampal neurons (S. Pyott and C. Rosenmund, unpublished observations) revealed an acceleration by a factor of 3 with the rise in temperature, comparable with our present findings. Despite differences in signal-secretion coupling between synapses and neuroendocrine cells (Chow et al., 1992), this evidence points toward a similar regulation of the size of the RRP.

If not limited by endocytosis, it will be interesting to test whether the temperature-sensitive steps in vesicle maturation can be further resolved by combined flash-photolysis and depolarization experiments. This would also allow for comparison with the quantitative predictions of the model of Voets et al. (1999).

\section{REFERENCES}

Albillos A, Dernick G, Horstmann H, Almers W, Alvarez de Toledo G, Lindau M (1997) The exocytotic event in chromaffin cells revealed by patch amperometry. Nature 389:509-512.

Arrhenius SA (1901) Lehrbuch der Elektrochemie. Leipzig: Quandt \& Handel.

Artalejo CR, Henley JR, McNiven MA, Palfrey HC (1995) Rapid endocytosis coupled to exocytosis in adrenal chromaffin cells involves $\mathrm{Ca}^{2+}$, GTP, and dynamin but not clathrin. Proc Natl Acad Sci USA 92:8328-8332.

Atkins PW (1986) Physical Chemistry. Oxford: Oxford UP.
Bittner MA, Holz RW (1992) A temperature-sensitive step in exocytosis. J Biol Chem 267:16226-16229.

Chow RH, von Ruden L, Neher E (1992) Delay in vesicle fusion revealed by electrochemical monitoring of single secretory events in adrenal chromaffin cells. Nature 356:60-63.

Chow RH, Klingauf J, Heinemann C, Zucker RS, Neher E (1996) Mechanisms determining the time course of secretion in neuroendocrine cells. Neuron 16:369-376.

Engisch KL, Nowycky MC (1998) Compensatory and excess retrieval: two types of endocytosis following single step depolarizations in bovine adrenal chromaffin cells. J Physiol (Lond) 506:591-608.

Gillis KD, Ed (1995) Techniques for membrane capacitance measurements. In: Single channel recording, pp 155-198. New York: Plenum.

Gillis KD, Mossner R, Neher E (1996) Protein kinase C enhances exocytosis from chromaffin cells by increasing the size of the readily releasable pool of secretory granules. Neuron 16:1209-1220.

Gomis A, Burrone J, Lagnado L (1999) Two actions of calcium regulate the supply of releasable vesicles at the ribbon synapse of retinal bipolar cells. J Neurosci 19:6309-6317.

Grynkiewicz G, Poenie M, Tsien RY (1985) A new generation of $\mathrm{Ca}^{2+}$ indicators with greatly improved fluorescence properties. J Biol Chem 260:3440-3450.

Hardingham NR, Larkman AU (1998) Rapid report: the reliability of excitatory synaptic transmission in slices of rat visual cortex in vitro is temperature dependent. J Physiol (Lond) 507:249-256.

Heinemann C, von Ruden L, Chow RH, Neher E (1993) A two-step model of secretion control in neuroendocrine cells. Pflügers Arch 424:105-112.

Horrigan FT, Bookman RJ (1994) Releasable pools and the kinetics of exocytosis in adrenal chromaffin cells. Neuron 13:1119-1129.

Kao LS, Westhead EW (1984) Temperature dependence of catecholamine secretion from cultured bovine chromaffin cells. J Neurochem 43:590-592.

Mansvelder HD, Kits KS (1998) The relation of exocytosis and rapid endocytosis to calcium entry evoked by short repetitive depolarizing pulses in rat melanotropic cells. J Neurosci 18:81-92.

Morgan A, Burgoyne RD (1997) Common mechanisms for regulated exocytosis in the chromaffin cell and the synapse. Semin Cell Dev Biol 8:141-149.

Moser T, Beutner D (2000) Kinetics of exocytosis and endocytosis at the cochlear inner hair cell afferent synapse of the mouse. Proc Natl Acad Sci USA 97:883-888.

Moser T, Neher E (1997a) Estimation of mean exocytic vesicle capacitance in mouse adrenal chromaffin cells. Proc Natl Acad Sci USA 94:6735-6740. 
Moser T, Neher E (1997b) Rapid exocytosis in single chromaffin cells recorded from mouse adrenal slices. J Neurosci 17:2314-2323.

Neher E, Marty A (1982) Discrete changes of cell membrane capacitance observed under conditions of enhanced secretion in bovine adrenal chromaffin cells. Proc Natl Acad Sci USA 79:6712-6716.

Park TJ, Lee IS, Ha H, Kim KT (1999) Temperature sensitivity of catecholamine secretion and ion fluxes in bovine adrenal chromaffin cells. Mol Cells 9:67-71.

Precht H, Laudien H, Havsteen B (1973) The normal temperature range. In: Temperature and life (Precht H, Christophersen J, Hensel H, and Larcher W, eds), pp 302-325. New York: Springer.

Renstrom E, Eliasson L, Bokvist K, Rorsman P (1996) Cooling inhibits exocytosis in single mouse pancreatic B-cells by suppression of granule mobilization. J Physiol (Lond) 494:41-52.

Smith C (1999) A persistent activity-dependent facilitation in chromaffin cells is caused by $\mathrm{Ca}^{2+}$ activation of protein kinase $\mathrm{C}$. J Neurosci 19:589-598.

Smith C, Neher E (1997) Multiple forms of endocytosis in bovine adrenal chromaffin cells. J Cell Biol 139:885-894.

Smith C, Moser T, Xu T, Neher E (1998) Cytosolic $\mathrm{Ca}^{2+}$ acts by two separate pathways to modulate the supply of release-competent vesicles in chromaffin cells. Neuron 20:1243-1253.

Stevens CF, Sullivan JM (1998) Regulation of the readily releasable vesicle pool by protein kinase C. Neuron 21:885-893.

Stevens CF, Tsujimoto T (1995) Estimates for the pool size of releasable quanta at a single central synapse and for the time required to refill the pool. Proc Natl Acad Sci USA 92:846-849.

Stevens CF, Wesseling JF (1998) Activity-dependent modulation of the rate at which synaptic vesicles become available to undergo exocytosis. Neuron 21:415-424.

Thomas P, Wong JG, Almers W (1993a) Millisecond studies of secretion in single rat pituitary cells stimulated by flash photolysis of caged $\mathrm{Ca}^{2+}$. EMBO J 12:303-306.

Thomas P, Wong JG, Lee AK, Almers W (1993b) A low affinity $\mathrm{Ca}^{2+}$ receptor controls the final steps in peptide secretion from pituitary melanotrophs. Neuron 11:93-104.

Voets T, Neher E, Moser T (1999) Mechanisms underlying phasic and sustained secretion in chromaffin cells from mouse adrenal slices. Neuron 23:607-615.

von Gersdorff H, Matthews G (1997) Depletion and replenishment of vesicle pools at a ribbon-type synaptic terminal. J Neurosci 17:1919-1927.

Wang LY, Kaczmarek LK (1998) High-frequency firing helps replenish the readily releasable pool of synaptic vesicles. Nature 394:384-388.

Weis S, Schneggenburger R, Neher E (1999) Properties of a model of $\mathrm{Ca}^{2+}$-dependent vesicle pool dynamics and short term synaptic depression. Biophys J 77:2418-2429.

Zucker RS (1999) Calcium- and activity-dependent synaptic plasticity. Curr Opin Neurobiol 9:305-313. 